\title{
Polycomb Protein EED
}

National Cancer Institute

\section{Source}

National Cancer Institute. Polycomb Protein EED. NCI Thesaurus. Code C101725.

Polycomb protein EED (441 aa, $\sim 50 \mathrm{kDa}$ ) is encoded by the human EED gene. This protein plays a role in transcriptional repression mediated by histone methylation. 